Routledge new horizons in South Asian studies

Series editors:

Crispin Bates

Edinburgh University

Akio Tanabe

Kyoto University

Minoru Mio

National Museum of Ethnology, Japan

Democratic Transformation and the Vernacular Public Arena in India Edited by Taberez Ahmed Neyazi, Akio Tanabe and Shinya Ishizaka

Cities in South Asia

Edited by Crispin Bates and Minoru Mio

\section{Cities in South Asia}

Edited by Crispin Bates and Minoru Mio 
Shil, J. (1876) Pulish Ghater Agnikanda. Calcutta

Sinha, D. (1993) Purbabanger Kobigaan. Calcutta: Calcutta University

Sinha, P. (1978) Calcutta in Urban History. Calcutta: Firma KLM.

Sripantha (pseud.) (1984) Mohanta-Elokeshi Samvad. Calcutta: Ananda.

Sur, A. (1988) Tinsho Bachharer Kolkata: Patabhumi o Itikatha. Calcutta: Ujjal Sahitya Mandir.

Tagore, K. (1930) Kolikatay Chalafera. Calcutta.

\section{The postcolonial street} Patterns, modes and forms

\section{Ajay Gandhi}

The streets of Old Delhi are not places of restraint. They are not even simply places of passage. On arrival there, the street may seem incomplete or spoiled; it is less a smooth asphalt carpet and more a misshapen organism. But it may be that this limitation is ours, not that of the street. If we examine its genealogy and enduring logic, especially in residual urban spaces, the street might make sense. The problem at the outset is that we are used to thinking of the city street, through time and space, in limited ways. Often, the street is understood merely as a functional conduit, intended for movement between one bounded place of sociality and another. Therefore, the street is relegated to a mere aside to where things are really happening: home and office, factory and field, temple and park. The street is a place to tune out, a necessary banality that we endure.

That streets should not be positive spaces but places leached of sociality is given impetus by the city map. This representation of the city streets does not change, whether we unfold the paper map or jab at a smartphone's Google Map. Stranded on a concrete pavement, we ceaselessly scan, in our mind's eye, seeking the panorama that gives comfort. To the modern person, trained to see from above, what is most comforting is that, on a map, streets always look the same. Two lines going left and right, up and down, the blankness within reminding us that the street is ideally vacant. This is the planner's street, overseen by the 'citizen's gaze' (Chakrabarty 2002). No wonder they have long been used to enforce strict segmentation: 'people here, traffic there; work here, homes there; rich here, poor there' (Berman 1982: 168)

Another, more romantic view of the street is based on the flâneur, who first emerged in the Parisian arcades of the nineteenth century: a bohemian who wandered the European street, both aloof from and immersed in the crowd. He specialised in roaming, avoiding a predetermined route or final destination. The street was the feedstock of this urban intellectual, a ceaseless source of inspiration.

Flânerie was of course not a democratic right; the street required, as for the planner, a cultivated manner. As the flâneurs' foremost exponent, Charles Baudelaire, wrote, 'Not everyone is capable of taking a bath of multitude: enjoying crowds is an art' (1997: 21). The flâneur turned the street, that seemingly equalising backdrop, into a high-brow text, legible only to those with a subscription. 
This snobbishness could only preclude empathy with those at the same altitude. The bohemian wanderer was intoxicated, yes - but also, inevitably, alienated (Benjamin 1983 [1973]: 50).

The flâneur - though rooted in a particular time and place - nevertheless found his way into the street at large. In the 1960 s, the situationists of Paris, selfstyled radicals, amplified the flâneurs' aloofness with their notion of dérive or drift (McDonough 2009). The one who drifted, the dériviste, also specialised in aimless walking, certain that state control was shaken with every step (no word on whether French authorities were commensurably troubled).

Other twentieth-century thinkers took up the mantle of the flâneur and dériviste, divining radical possibility in the humble street. The walker on Manhattan's streets, for example, was said to practice a 'delinquent narrativity', defying larger imperatives (de Certeau 1988 [1984]: 130). Walking in the city, with 'tactile apprehension and kinaesthetic appropriation', was a radical statement (de Certeau 1988 [1984]: 97).

Prevailing notions of the street, then, encompass the citizen's gaze and the planner's inscription. We also remain in thrall to the flâneur's wanderings and dériviste's hubris. These ideas have found periodic popularity far afield, in places such as India. In the mid-1970s, during what came to be termed 'The Emergency', democratic rights were suspended. Fetishists of civic sense and rational planning in Delhi used the opportunity to carry out an extreme makeover: its streets became laboratories for a high-modernist vision borrowed, predictably, from Paris's facelift after the French Revolution. Nexuses and mafias were to be smashed, the streets fastidiously scrubbed. The planners's zeal underwrote, in the form of demolition squads and police arrests, the erasure of tens of thousands of members of the streets' underclass (Tarlo 2003).

If this was a ruthlessly efficient vision of the street, there was also its selfconscious romantic. So it is that observers of Kolkata note how its rooftops, parks and streets host adda, a genteel form of gossip and debate (Chakrabarty 2000: 201). Just as proponents of flânerie saw themselves as superior to capitalists, adda ideologues give it an anti-teleological aura. The practice is 'opposed to the idea of achieving any definite outcome' and stalls the march of progress (Chakrabarty 2000: 204). The adda and the street, in this view, belong to a highminded class coeval with, if ambivalent about, urban modernity.

On closer inspection, these become celebrations of privileged outlook, not descriptions of commonplace experience. They universalise a certain kind of bourgeois, modernist city, even where art-deco arcades are absent and sidewalks are chewed up. Imagine if citizen and planner, flâneur and habitué of adda, were dropped onto the streets of Old Delhi. Their turf would be unrecognisable. The planner, anticipating a linear, functional void, would see instead, on Lal Kuan Bazaar Road, a space used for card-playing, slogan-raising, cow-grazing, procession-conveying, and tooth-brushing. Far from being an innocuous and aseptic space, the street would be abundant and multifarious.

On Ballimaran Road, the flâneur, determined to stay removed from the crowd, would be accosted for money, jostled by hand-carts and rickshaws, assaulted by fumes, and overcome by honking. Rather than extricating himself from the crowd, he would be assailed, drawn helplessly into the vortex of the street. On Fasil Road, the adda-seeking poet, in search of bourgeois company, would find a different scene: workers from the countryside congregating in ganja addas, huddled circles of hashish smokers. Capitalism, no doubt, would be deficiently realised - and the canon of verse may not extend to Bengali poets. Adda in Old Delhi is a male activity associated with unemployment and undesirables. At the tea stall or crouched at a traffic junction, high on various stimulants, men verbally joust, taunt women and horse around (Jeffrey 2010, Mehta 1997: 226). That other admirer of the street, the dériviste, might find it less conceivable to drift on the streets bordering the Meena Bazaar, should a political jaloos or procession, with thousands waving placards and shouting slogans, impede his passage. All these icons of the street, after visiting such an area, would need to go back to their blueprints and notebooks, and re-imagine the street on its own terms.

How can we make sense of these features of the postcolonial street? This chapter employs concepts that may help to revise this ubiquitous feature of urban life. Any visitor to the Indian city will know how distinct the street is as a social space. It is perpetually charged and potentially dangerous; it contains the ordinary friction of difference and desire, which can suddenly mutate into a malevolent crowd. Yet we lack a vocabulary for understanding how sociality unfolds - in aggressive, organic and disorienting ways - on the street.

Instead, writers often revert to the notions advanced above, the stern gaze and romantic musings of those who objectify the street but rarely dwell on it. Based on ethnographic fieldwork conducted in 2007-09 in Old Delhi, this chapter tries to sketch some of the street's defining features. These reflections are packaged with some rubrics for conceptualising the street. The following terms are suggestive of recurring patterns, modes and forms that define an Old Delhi street, and likely other postcolonial streets as well: abundance and plasticity, osmosis and porosity, and altitude and adjustment.

\section{Generic and specific streets, material and spectral streets}

When I began my fieldwork, I did not plan to spend much time on the street. The street, if ever I thought about it, was the mere in-between: from home to shop to bazaar, and back to home. Over time, however, I realised that I was sometimes spending hours on the street. It was to me what an interior space, the living room or factory floor, would have been to another anthropologist. My fieldwork was concentrated in two markets, Meena Bazaar and Khari Baoli, and nearby mandis, or congregations of construction labourers. It was on the streets that daylabourers sat while they waited for work. It was there that religious processions or political demonstrations unfolded. It was there that the euphemism of urban rationalisation came alive as police charges and municipal seals.

To subsume these material-psychic dynamics under the rubric of a generic street is to gloss over subtle distinctions. Just as circumpolar peoples have an 
intricate taxonomy for snow, Delhi's residents possess various names for the street. There are galis or lanes, usually no more than a few feet wide, found within dense mohallas or residential clusters; the lane is not simply a cramped space, but a sociological marking: this extended family, those sect members, live in that lane. Related are kuchas, usually referring to slightly longer lanes, still horizontally compressed, but extending further than a mere lane.

Kuchas and galis were the most distinctive features of medieval urban planning. Originally they were clay and dirt; they are now covered with an evervanishing veneer of asphalt. They lack separate spaces for vehicles and pedestrians, and they do not possess the right-angled corners and straight lines of this-or-that road, place or circus, names which mark the colonial and postcolonial street (Vidal \& Gupta 1999). Galis are perhaps the best evidence of how state power was not definitively inscribed into the functioning of the street. Rather, lanes are known by several names simultaneously, referring to longdisappeared objects or residents, as well as newer structures and nationalist heroes (Oldenburg 1976: 30-31).

After galis, there are larger, more prominent streets in the old city; these are sadaks, literally streets, or chowks, referring to prominent commercial avenues. These are of precolonial or postcolonial vintage, and are usually wider and more congested. Nai Sadak, for example, literally, New Street, was a straight line built by the British in the late nineteenth century; it now houses a textbook and garment bazaar. Chandni Chowk, the main commercial thoroughfare of the old city, was constructed by Mughal planners as a canal-lined promenade. It is now an exhaustand-people filled avenue packed with religious institutions and cloth shops. ${ }^{1}$

One could think of these various street as different formats, as a technomaterial substrate which catalyses expression. Urban scholars often use the metaphor of city as text; yet if its constituent spaces are thought of as legible, they cannot be read with the comfort of linear pagination or an actual text. Their constitution and makeup demand reading between the lines, dispensing with the notion that they are singly inscribed. Nor do such places have a single author. This is the perennial problem for Indian planners: there are too many encroachers, too many loafers, who write themselves into the city, contributing towards 'unauthorised' hawking and dwelling. A more enduring analogy for the street may be provided by other techno-material formats. The streets of the old city were overwritten many times, like a re-writable tape, scratched and grooved by its many handlers. Indeed, the street groaned under such intense activity. Broken and potholed through overuse, hissing and crackling, overrun by its many encroachers-cum-unauthorised-authors, the street was a form that nevertheless hummed the city's tune.

\section{Sheer abundance}

In the circular whorls of the old city lane or the straightness of the street, there was no segregation of activities. Rather, the street was a place of sheer abundance; there was hardly a financial deal, political statement or bodily activity that did not occur there (Chakrabarty 2002: 73). For example, on Chandni Chowk, my path was frequently interrupted by political rallies. Local parties would set up a tent and dais on this street, in front of a municipal office. Where vehicles ordinarily skirmished, hundreds of the faithful sat, becoming animated when speeches were given. They became even more animated when food was served afterwards. Speeches were to be endured; at least one got some food out of it (chalo, kuch khane tho mila). At such moments, the street easily became a plact for political spectacle.

This abundance was also evident on Gali Mata Wali, where men rolled carts loaded with kerosene burners, chickpeas and potatoes. Thick smoke blew over hungry passers-by, and they doled out some local culinary favourites, such as tikkis - fried vegetable discs containing potatoes and peas, served with a tamarind sauce or ketchup. The street was, with little contradiction, kitchen and dining room. Indeed, the thrill of eating on the street was part of the seduction of the old city; to consume street food was to ingest something true about the place. Another facet of the street's abundance could be seen at night. As the sun set and the old city, unevenly lit, became dark, Urdu Road, bordering the Meena Bazaar, became dotted with prostitutes. This was no red-light area, just a regular street, used to drive and hawk and beg during the day, where single women with bright makeup and bold stares stood at night. The street was, thus, also a boudoir.

In these ways, the street's florescence, on mere grey asphalt, was somehow hum-drum: a low-level volatility rendered ordinary. But its kinetic energy could be amped up, punctuating the entire area. When a religious procession moved through or when rumours emerged of a municipal raid, the streets of Old Delhi became an ordinary space where extraordinary tensions could suddenly swirl. It was on the old city's streets, for example, where hours after Indira Gandhi's assassination in 1984, crowds stoned, stabbed and bludgeoned Sikhs. ${ }^{2}$ The street's abundance overrode original design. It was overwritten and overbrimming. ${ }^{3}$

\section{Too close for comfort}

The old city's streets - its intimate alleys and appropriated sidewalks - were radically unlike the roads and flyovers of New Delhi. Like its prosperous classes, the new city had ever-enlarged and ever-clogged arteries. These diseases of prosperity required multi-lane bypasses and flyovers, emergency measures in a wheezing megalopolis. The grey totems of progress were much-heralded in Delhi's newspapers: finally there would be clear flow. But often the opposite occurred: more sclerotic jams and road rage. These streets nevertheless suggested a single-minded competition to get ahead, to keep ahead of the scrum. On the flyover, the sheer volume of metal and exhausts arcing through the air blotted out human presence, save for the beggars at stop-lights.

In contrast, what was undeniable about the old city's streets were the breathing, sneezing, laughing and sweating others, the pushing, elbowing and spitting evidence of humanity. One could, without much effort, go sideways and backwards, 
pause and listen, feel and touch. Intimacy mingled, in such places, with prosaic routine, and bodies with snippets of devotion. On streets such as Malliwara, jewellery merchants made orders on their mobile phones, their chatter mingling with devotional songs from speakers. On Tilak Bazaar Road, migrant labourers had their ears cleaned and stubble trimmed over the sidewalk drain, alongside commuters haggling with bicycle-rickshaw drivers. The street was replete with many such instances of 'wild connectivity' (Hansen \& Verkaaik 2009: 21).

What about the relationship of the subject to his peers in the crowd? In the old city, the street was not a place, as with the flâneur, where the pedestrian could mentally retreat from the crowd, gazing undisturbed at the arcade. The daydreamer, both lost in and aloof from the crowd, gave way to the selfconscious and ever-vigilant walker. In my experience, the streets of Old Delhi were the venue for endless, often involuntary, negotiation. Dalals or brokers hashed out deals and filled in paperwork for railway tickets and government certificates on the kerb. Touts exhorted passers-by to purchase things they might not need: sex, dried fruits, a four-pack of underwear.

For women especially, the street was suffused by the male gaze, and often a place of unwanted advances. Women were loudly compared to buttery sweets and fried snacks, gastronomic and sensual pleasures. The inability to conceptualise the female street-walker except in pejorative terms is not surprising. The imagination of urban India - in films, gossip and innuendo - often focuses on a male protagonist. The women of Delhi were not neutral wanderers on its streets. Their mere presence on the street made them fair game for grabbing and glaring, fondling and cat-calling.

A similar discomfort in being the watched, not the watcher, was evident amongst the street's underclass. For migrant workers, thinking of the street as a distanced muse, as it was for Parisian bohemians and Kolkata's poets, made no sense. The street involved involuntary intimacy and exchange, a perpetual jostling where one could not, like the flâneur, forget oneself. One was in the thick of, not removed from, the street and its gossip, deals and threats. And being of the street meant that one could not have a bourgeois propriety over it. Those deemed to have a proletarian disposition - of a particular complexion, with a scrawny build, often wearing plastic sandals - were frequently targets of interrogation: for sleeping on the streets, for not possessing valid identification and for simply being in Delhi.

\section{An equal altitude}

However unequally they were experienced, these streets could be considered the most democratic in the city. They were open to all comers: educated and impoverished, engineers and junkies. In the old city the street functioned, as the 'Arab street' did in a different context, as a shorthand for authenticity, for the pulse of the polis. Old Delhi's streets were the parts of the city where adventurous citizens got their dose of culture (consuming potentially lethal street food), and the popular classes gravitated for work (minus life-saving safety equipment).
Migrant labourers, for example, avoided New Delhi, which sprawled in all directions away from the walled city. Befitting its colonial origins, the new city was defined by gates and chowkidars (night-watchmen). Police posts and concrete walls frosted with shards of broken glass separated out the right and wrong kinds of people.

In contrast, if there is a singular feature that connects Indian streets, it is their startling heterogeneity. In this respect, my disorientation in comprehending Old Delhi echoed the seeming mutual unintelligibility of its residents. On the streets of Old Lucknow, 'people do not conform to any single social system, tradition, or standard of public conduct through which their diverse identities can be mutually understood' (Hjortshoj 1979: 35). This state of enduring disinterest shown by myriad kinds of people to one another on the street offered, especially for the urban proletariat, some entertainment and a resting place, a conduit of news and opportunity.

\section{Eyes on you}

The abundance and indifference of the street did not preclude individual focus. People on Indian streets seem to possess innate noise-cancelling capabilities, dulling the roar of the crowd. Indian leaders and intellectuals have long argued that denizens of the Indian city are selfish or un-self aware (Chakrabarty 2002). But it may be that those on the street are simply determined, despite its distractions and threats, to get their work done. I found it common, for example, to have conversations with arhatiyas and banias (commission agents) on the streets of the Khari Baoli spice bazaar. I had trouble keeping up with our conversation; they had no trouble, on the other hand, conducting an interview, negotiating on multiple mobile phones, dealing with the packaging of various goods, calling out for tea, directing palledars or loaders to move things here or there, with ceaseless honking and bartering all around. This watchfulness was also evident when I habitually returned to a few chai stalls squatting on the street, prime venues for gossip and rest. More than two dozen mobile and stationary tea-sellers dotted the vicinity of the bazaars and labour mandis where I conducted fieldwork, selling tea to labourers, brokers and merchants.

Shortly into my time there, it emerged that two of the tea-sellers I frequented were khabaris, or police informers. They mastered the quotient of milk, cardamom, tea leaves and water, while keeping in mind the squat clay or plastic cups doled out here and there. Alongside these banal tasks they mastered and kept mental track of the street's coming and goings. Listening in on conversations, knowing who was doing what, they were conduits of khabar, or news. As such, they were indispensable to Delhi Police constables, whose beat mostly consisted of sitting in the dark, cool chowkis nearby. It was through the tea-sellers' eyes and ears that the volatility of the street was regulated. By dispensing khabar, officially notified BCs - Bad Characters - were tracked, and hafta - protection money - levels regulated. The chai-wallahs-cum-khabaris were not simply the eyes of the state, outsourced panoptic functionaries. These same men were put to 
use by traders in the old city's bazaars, tipping them off when municipal raids occurred. It made little sense to think of the citizen's gaze on the street as hegemonic; the man of the street had dispersed loyalties. Therefore, the street planner never subdued his target; people simply stared back.

\section{Liquidity}

It was striking, during my time in the old city, to see which street presences endured or disappeared. However useful the tea-seller was, the informer's hold over the street was not to be taken for granted. The tea-seller-cum-informer, too, had a tenuous claim on the street, at once indispensable and interchangeable. They were kept on edge by their uniformed protectors and invariably embroiled in contentious negotiations with their neighbours on the street. Months passed and more than one such stall, overseen by men who doggedly returned to the same spot over time, vanished. When I asked around, people seemed hardly to notice. It seemed to be a matter of course that the street could take on one avatar and then another. There were other tea stalls at which to congregate, different informers that the police could cultivate.

This fluidity inflected the legitimacy of the street's persons and buildings. Bicycle-rickshaws, repeatedly outlawed by the Delhi courts, nevertheless proliferated in the old city. According to the law courts, they were gone, a menace erased; but hundreds nevertheless remained. Elsewhere, in the Meena Bazaar, around the Delhi Junction railway station, and all around Chandni Chowk, many hawkers sold their wares. Singularly powerless, they were expressions of the power of local patrons, facts on the ground that affirmed the sway of big men. Despite the rising temperature of Delhi's High Court justices, it seemed that the logic of the street, not legal prescription, was sovereign. Landlords and businessmen I met were guilty of 'encroachment', the official term for improvised building. Their hotels, now three storeys instead of two, their shops jutting past their legal perimeter were, nevertheless, here to stay. When faced with official pressure, the owners would 'regularise' them by paying a fee and obeisance to officialdom

\section{Street as adjustment}

We have seen how the Indian street is not the same symbolic ground on which the storied flâneur of nineteenth-century Paris roamed. There was, in western cities, a clear distinction between the pavement and arcade, and vehicular and pedestrian traffic. For Delhi's officials, too, the pedestrian pavement, clear and clearly demarcated from the vehicular road, residential colony and commercial arcade, was an abstract ideal. The street, after all, was the circulatory system of the city, critical to its productive momentum.

We might imagine the flâneur in the old city, falling into open sewer drains, shoes covered in the excrement of goats and cows, twisting an ankle on the sidewalk's abrupt holes and jagged crevices. The street of the old city, in physical and social form, was not so much imperfectly realised as differently enacted Ending abruptly, colonised by entrepreneurs, uneven and broken, Old Delhi's residents traced an unpredictable route through crowds, vehicles, stray animals and other obstacles. All of this is why the Indian street seems so untamed in the scholarly imagination. The men invariably urinating on Indian streets are paraded as examples of defiant unruliness (Khilnani 1999: 124, Chakrabarty 2002: 68). Yet, despite the appearance of chaos, the longer I spent in Delhi's old city, the more the street's internal logic became evident. As in many Indian black towns, this most undifferentiated of urban spaces was precisely allocated and occupied: to a cigarette seller here, to a public-phone vendor there and everywhere to the enterprising and strong-armed. ${ }^{4}$

In this milieu, the Indian street was governed by the metaphysics of adjustment. One of the chai-wallahs mentioned earlier, whose stall I habituated and who later vanished, told me about his observations of the Biharis and Rajasthanis and Jharkhandis who worked in the old city's bazaars. Yes, he said, there is tension, and regular sorts of panga, scuffling. Moreover, on streets, one's nerves frayed and one wearied from dhakka-mukki, being tossed to and fro in the crowd But on the street, he said, 'sab adjust karna padta hain': 'They all have to adjust.' The planner has to adjust and realise that the master plan for the city wil never be realised; the home-owner has to adjust and share his alleyway with workers and encroachers; the police have to adjust and accept a certain unruliness and opacity. And of course the chai-wallah, elaborating this theory to me, had to adjust to the fact that he was then on the street but might soon disappear. Adjust karna - to adjust oneself - means that one cannot reliably control the claims of others on your space. It also means accepting that your own claim to that space can be solid today, and melt tomorrow.

\section{Porosity and osmosis}

On the street where one had to adjust, no enduring division could be made between public and private activities (Appadurai 1987: 17, Chakrabarty 2002: 66). Yet public and private seem to be inapt categories for what happened on the streets of Old Delhi. Better terms for street life might be osmosis and porosity. Certain things we think of as private or intimate, done out of compulsion or habit, crossed the permeable barrier of comfort or shame from one domain to the other. For example, on Sita Ram Bazaar Road, merchants of nearby iron-wares stores soldered and assembled goods in the middle of the street. Like other bazaars in the old city, resembling closets that had burst, goods were invariably scattered in the street, to be processed and shipped in due course. No conscious decision had been made, nor official sanction given; imperceptibly, as if by osmosis, things moved from one place to another. The streets of the old city were simply full of stuff, which was moved from godown (storehouse) to pavement, from trader's desk to kerb, from basement workshop to goods carrier.

This is not to say simply that things moved from a clean, private domain, to an unruly, public one. The street has been described as 'the outside, the space for 
274 A. Gandhi

which one did not have responsibility' (Kaviraj 1997: 98). Against the home, a seeming sanctuary, the street has been seen as a place of moral impurity and strangeness (Chakrabarty 2002). But these distinctions confuse the gaze of the citizen with the street's autonomous ethos. Both people and things on the street belong to someone, and are subject to overlapping claims. The circulation of everything from hazardous chemicals to Nepali prostitutes from interior to exterior does not mean order becomes disorder. If anything, the old city's street allows a different kind of public, one unimaginable on the flyovers of New Delhi. A writer discussing similar streets, the galis or lanes of Banaras, notes that residents 'always treat the lanes outside their house as truly public space, as belonging to them. There is no clear or closed boundary between house and outside. Almost all recreations - sitting and relaxing, drinking tea or having pan - take place in the galis' (Kumar 1988: 77).

\section{The street's avatars}

If this is correct, Old Delhi's street can be considered a set of disguises or masks. The Indian street does not revert to a 'normal status' or 'normal function' (Kaviraj 1997: 106). When one looks at photos of Old Delhi's street life over decades, it is difficult to ascertain when they were taken. It is not as if the street has become more or less frenzied, with more or fewer people. Looking at a street scene over time, no one configuration of stalls, hawkers and encroachments can be considered the true or lasting one.

Old Delhi's streets may have had different material incarnations - from clay and dirt in the nineteenth century to metallised asphalt in the twentieth - but temporally no predestination. The municipality's reiterated promise to clean up the street was itself a kind of disguise, a contrivance which held that its real face, underneath all of the handbills and wires, was obscured by illegitimate improvisations. If one took the streets surrounding the Jama Masjid and Meena Bazaar, for example, there was neither a strict daily routine nor seasonal rhythm to street life. I initially noticed a division of labour that matched this space: during the day, these streets were occupied by hawkers, visitors and beggars; at night, they were taken over by prostitutes, migrant labourers and junkies who slept in the open. What the streets were meant for, driving and walking, were merely two things happening on them. During religious festivals such as Eid, or national holidays such as Republic Day, the temporality of these streets changed once more; families could be found strolling and snacking at night, or the entire area shut down and darkened because of police curfew. There was no normal or default in such streets, simply accretions and deletions, one visage superimposed on another.

The shifting avatars of the street were most clearly visible in the Lego-bricklike additions and subtractions to kerbs in the old city. I heard shopkeepers and residents narrate how tiny religious idols, placed next to an electricity transformer, evolved into a tiny shrine, and then, years later, a hulking temple. As in other Indian cities, the street could be imprinted with religious posturing. A good
The postcolonial street 275

example was near the Kashmiri Gate auto-parts bazaar, where I often passed a roadside agglomeration of Hindu deities. Nested into a sparklingly white-tiled frame, about waist-high, were statues of Ram and Sita. I had done some interviews with Punjabi traders nearby. A group of them had pooled some money no one could precisely remember when - to build this edifice. What was intriguing, though, was that this hijacking of the kerbside was not just an exercise in piety. Several of the traders had been threatened by various archaeological and municipal authorities with the closure of their storage and commercial premises. Much of this was because their bazaar - widely known to recycle autoparts from cars stolen and stripped in Delhi and Uttar Pradesh - had appropriated swatches of a heritage zone, awash with Mughal and British colonial buildings.

In cities, what reigns in the present may sideline the past. The trader's shrine was modest in comparison with the towering churches and 100-300-year-old walls nearby. But their humble agglomeration of deities made municipal action against traders inconvenient. Those traders were the ones, after all, who held sway over the authorities. And even if the street-side shrine was a fig leaf that they were holding in front of naked commercialisation, a municipal demolition of their premises would have been less an act of authority than of callousness. An analogous process occurred elsewhere on India's urban streets. In Bangalore, the profusion of shrines gobbling up its streets was met with municipal silence; so as not to tramp on religious sentiments, and to keep order, the law was overlooked and sidestepped (Nair 2005: 154). Seen in this light, the Kashmiri Gate street temple, at one level an illicit appropriation of public space, was on another a down-payment on the future presence of the traders. It created facts on the ground, material evidence of the wilfulness of certain parties.

All such material manifestations in the city, of course, are expressions of power. Good examples could be found near the auto-parts bazaar. The old city's imposing Jama Masjid was built on elevated ground by Mughal emperor Shah Jahan in the late seventeenth century; a similar desire to awe supplicants underwrote the British-built Parliament complex in New Delhi. One hundred years hence, writers of Old Delhi might see its heritage in terms of the street improvisations of the present. The humble white-tiled clumping of Hindu deities, located in a near-forgotten side street near Kashmiri Gate, would perhaps by then have grown from waist-high sapling into something much grander. For now, though, the temple was simply another brushstroke on the street's crowded facade.

\section{The street as shauk}

The pressures of the street - open to all takers, yet claimed by few - were made further visible by the old city's migrant workers. Consider the case of Rahul. A mistri, or construction labourer, who assisted a mason, I met him at Haus Qazi Chowk, close to the Meena Bazaar, along with dozens of fellow migrant labourers, their tools and paintbrushes arranged before them. As the old city came to life, cows, rickshaws and cars circumnavigated this roundabout, where several wholesale bazaars - selling paper, iron, kites and tools - converged. The men, 
almost all of them migrants from Uttar Pradesh, Bihar and Rajasthan, were usually between their early twenties and late forties. As day labourers, they were entirely at the mercy of contractors who inconsistently offered painting, plumbing or masonry work. The men began their vigil early in the morning, by 7 a.m. By 1 p.m. whatever work that was to arrive had come. On many days, the numbers of men remaining at Haus Qazi Chowk testified to the lack of work, at least of the consistent kind.

The street, more by default than proprietary claim, belonged to them. Only for the richer and more productive was it a conduit to more pressing business. For the workers at Haus Khazi Chowk, the street itself was where they were coming from and going to. Others in the old city, traders and brokers and tourists, went to and fro. Their physical posture and mechanical accompaniments suggested people already somewhere else: sitting on rickshaws and in cars, a mobile pressed to their ear, wearing ironed, brand-name clothes.

Meanwhile, a few dozen of the labourers at Haus Khazi Chowk sat, crouched and lay down on the street. For them, the street to somewhere was too often a way-station to nowhere. Still, when the street did not serve as an avenue to work, it allowed one to do activities that disguised how stuck one really was. On the Chowk itself, workers had a number of options: playing cards (tash khelna), drinking country-liquor (daru peena), reading the newspaper (khabar parna) and following the numbers game (satta-bazzi karna). These were activities that comprised the long-standing economy of shauk, enjoyment and effervescence (Kumar 1988).

A special taxonomy of activities comprised language games. Among men who may not have work and were wandering in situ, verbal jousting substituted for action. There was everyday gossiping (gup-shup marna) and simple chit-chat (baat-chit karna). When talk of one another or families had run its course, things got silly: the time for idle or nonsense talk, so pointless it was termed 'the fucking of words' (bakchodi or muhchodi). Restlessness and masculine oneupmanship led to teasing. A whole afternoon could be passed by pulling one another's legs ( $e k$ dusre ko lenalek dusre ko chedna). Usually these were accompanied by a barrage of galiyen or abuses. A similar need spawned a vast corpus of mazaak, homoerotic puns or pranks (cf. Ramaswami 2007). The more creative of the men at Haus Khazi Chowk would recite famous filmo ka dialogue, or lines from Bollywood films. Some rehearsed sher-o-shayaris - rhyming couplets about love and loss. Sometimes these were subtle and chaste; at other times they veered towards the vulgar and irreverent, putting them in the category of salacious stories (mazedar kahaniyan).

\section{Time-pass}

When I met him, Rahul was a young man in his early twenties, not yet sufficiently skilled at his work to become an ustad or guru - a master who would train others. Like the other young men at his mandi, by midday, if no work was to be had, he started ghumna-phirna, or roaming Old Delhi's streets. Rahul usually had very little money in his pockets; his aim was hardly ever to buy something or fulfil a task. But this roaming was not done with the flâneur's conquering passion or superior lording over the crowd. For the migrants of Haus Khazi Chowk, whatever pleasure there was to be had was in time-pass, referring to the state in which someone could be doing something better or productive but was condemned otherwise. A middling 1980s Bollywood film, watched at the nearby Excelsior cinema, was time-pass. In a similarly unenthusiastic way, squatting with friends on the street, listening to a qissa, a meandering historic tale, was time-pass. Sitting with an anthropologist, who asked unnecessary questions over and over again? A quite unsatisfactory form of time-pass.

Time-pass was not simply an adjective referring to an activity done in downtime. It could encompass the condition of an entire class of underemployed and frustrated men. Shopkeepers at Haus Qazi Chowk, for example, termed young men like Rahul sadak-chhap admi. To be chhap was to be stamped or moulded, in this case by the sadak or street. The sadak-chhap admi were not just men who happened to be on the street, but men who were rather stamped by and melded with the street. A similar conflation of locale and person was found when I interviewed police about law and order problems. For them, crimes were mainly caused by the footpath log or pavement log, literally, sidewalk or pavement people. Moderately educated or skilled, but lacking job opportunities in government service or the private sector, tens of millions of men like Rahul were to be found on the streets of Indian cities. Loitering at traffic intersections, clustered around chai stalls, they are among many considered to be "wanderers", "useless men" or people engaged only in "timepass"' (Jeffrey et al. 2008: 169). Added to their numbers are the drivers, cleaners, street performers and beggars who physically overwhelm the street but are absent from its consciousness.

I heard Rahul sometimes refer to his life and that of his friends in the same pejorative vocabulary hurled at them by their social betters. Describing himself as illiterate (anparh) and careless, he spoke with irreverence - as if he did not care - and bleak self-assessment. Usually in debt, hobbled by illness and insecurity, Rahul's fellow workers also talked of their doomed fate and wasted lives. Here time-pass was not simply a few transitory hours or months, but a default state of being.

\section{Pathway to somewhere}

This immobility did not mean that Rahul retreated from the streets. For him and his friends on Haus Khazi Chowk, the street was the only guaranteed place to rest one's head, while away the time, and find an opportunity. It was most obviously a place for ghumna-phirna, wandering or roaming about (Kumar 1988). Ghumna was an ambivalently undertaken ethos that pointed to the street's simultaneous flux and immobility. On the one hand, it was an aspect of city life that cost nothing, and so precluded workers' discomfort at being in other spaces. Simply to be a migrant to the city, to have the dubious privilege of sleeping on Delhi's streets, was an outcome of being a ghumnewale. 
Rahul and his friends, most of them from eastern Uttar Pradesh and western Bihar, were in their twenties. This was the time when, back at home, in their villages and towns, it was normal for a man to wander about. The ghumnewale was the one who wandered from the streets of their smaller, less promising village or town, and headed for the promise of the metropolis. This implied not a local walkabout, but a metaphysical transformation; such men were expected to go to bigger cities and higher pay-cheques. Rahul himself had spent time in other major Indian cities, working on construction projects in Meerut and Nagpur, after which he ended up in Delhi's old city.

For workers in the city, ghumna-phirna, on a local scale, was the one thing that was in their control. Indeed, from the vantage point of the ghumnewale, the streets of Old Delhi were qualified places of pleasure. If someone like Rahul had tried to enter a middle-class temple complex, he might be shouted at by its caretaker, based on his tatty plastic slippers. He told me about walking in the posh shopping arcade south of the old city, Connaught Place, known as CP. He did not like how he was stared at and made to feel ajib, strange and uncomfortable. Chastened by the memory of being amidst the middle-class people who strolled there, he would not contemplate a return visit: 'accha nahin lagega' - 'I won't feel good'. Seen in this way, the streets of Old Delhi precluded being under control, and also allowed for certain small pleasures, unlike in the regulated colonies of the new city. Despite worries about money and work, the men of Haus Khazi Chowk seemed by and large to prefer their casual, freelance lives. I was told that unlike salaried work, which made one a slave (gulami) to time and vertical pressure, the intermittent nature of construction work made them free birds (azad panchi).

Seen from this perspective, the ability of men such as Rahul to piss where they liked - on a shuttered storefront at night, against the compound wall of a government building during the day - reflected a relaxed disposition towards the city (Kumar 1988: 79). For such men, the street was a place relaxed enough to let one's bladder and sphincter slacken at will, without shame or discomfort. (Conversely, for women in Delhi, the tension with which they experienced the street was reflected in the consequences of holding things in. $)^{5}$

The Indian street, in the enabling ways of the ghumnewale, has long been overwhelmingly male and popular. In nineteenth-century Banares, in Uttar Pradesh, "recreation for lower-class males frequently consisted of simply "roaming" the streets of the mohalla' (Freitag 1989: 123). In Bombay, mill workers in the early twentieth century also used the street for roaming, pausing to congregate in front of liquor shops or street entertainers (Chandavarkar 1998: 103-104). Historically in Lucknow's old city, 'the street itself was a destination and an event', a place to gossip, mingle, and barter (Oldenburg 2001 [1984]: viii).

\section{Treadmill to nowhere}

Yet there is another association to the street. For, despite these men talking and dreaming on the streets, they could not completely disguise their inactivity. Once in the city, the migrant who engaged in ghumna-phirna could become stuck. The city's promise could be illusory; the big payday deferred once again, over and over. Thus the other meaning deriving from ghumna - against the romance of a young man wandering cities for a time, before heading home triumphal - was of the ghumte phirte admi. This was a pejorative term applied to migrants, wanderers with a lack of employment and status.

Rahul's relationship to the street differed in this sense from that of the flâneur. The bohemian was supremely confident, at all moments superior to the crowd; the migrant labourer might enjoy the street too, but this was tempered by pathos. The same freedom that the street brought to plumbers and masons could become a millstone around their neck. Consider the language used to describe such men in Delhi: bekaar, useless and idle; or lafanga, an idle and useless wanderer (Jeffrey et al. 2008). The lack of a formal work contract that the workers saw as making them free birds was at other moments seen as a cause of shame. Rahul, for example, admitted that his inability to save a significant sum for the marriage of his siblings had ruined (barbad) his family relations and led to him drinking more and more.

Indeed, the terminology for forward momentum on the street could come to mean thwarted fate. Rahul's colleagues sometimes had trouble collecting their payment from contractors. Often, when they demanded their due, they were told excuses: come back tomorrow, there is a delay, you will get it next time. 'Ghumate rathe hain', they said - 'They simply turn you round and round.' In the old city, these men had imagined their life going forward, like the long, straight street; but often they spun in circles, their paths blocked. The street could take on a darker tone, where one was not simply immobile, but obsolete. Indeed, like other members of the old city's underclass, such as drug addicts, the workers at Haus Khazi were not briskly walking on the street, but stuck sitting on it. Baithne or sitting allowed for entertainment, like the reciting of sher-oshayaris, as mentioned above. It was a creative posture, one that was in some ways productive of dialogue and exchange. But it was also one that indicated one's idleness and immobility (cf. Dhand 2006). 'Hum log bas baithe rathe hai', the workers would say in frustration: 'We are doing nothing but sitting.'

The street, for such migrant workers, was both pathway and trap; the latter valence was evident in the use of the term lawaris. Monthly, migrants who had become destitute or addicts, were found dead on Old Delhi's streets. The police would post notices in front of stations or in newspapers; the men, usually lacking identification, were termed 'unclaimed' or 'lawaris'. The old city's police also sprung into action when forgotten objects were left on the street, such as large parcels or suitcases (lawaris vastu). But most of all, lawaris was applied by migrants to one another, in jokes that carried an undertone of anxiety. To be lawaris was to be a bastard, lacking clear parentage, like the dogs that slept alongside the men at Haus Khazi Chowk. Metaphorically, though, it denoted a certain type of unrooted person in the city, the migrant labourer most of all. The street contained the freedom of ghumna-phirna, or wandering, and the danger of becoming lawaris: unrooted, forgotten and unclaimed. 


\section{The stubborn street}

The citizen did sometimes show up on Old Delhi's streets. The monumentvisitor, bazaar-shopper and atmosphere-seeker, though, came with numerous injunctions, orders and recommendations. Behaviour was scrutinised and con doned or condemned in a capitalised officiousness. The municipal signboard, suitably vague and terse ('commit no nuisance') to encompass almost anything was the best example of the 'standardising techniques' of the Indian city (Kaviraj 1997: 85).

Outside of the street, these were urban instructions for mis-use or non-use. The visitor arriving at the Delhi Junction Railway station encountered this sign: PUBLIC NOTICE: STOP PUBLIC FEEDING OF MONKEYS. At the Golcha and Excelsior cinemas in the old city, signboards and tickets noted a long series of items under the heading: FOLLOWING ITEMS STRICTLY PROHIBITED. At the Delhi Metro stops located at Chandni Chowk and Chawri Bazaar, the two old city stations, there was a long list of Dos and Don'ts, of Dangerous Materials and Offensive Articles. At the Mahatma Gandhi park, located near the old city's Katra Neel textile bazaar, a hand-written sign stood in one section that was closed off with a chain and lock. It read, without further explanation, 'No Entry: By Order'

Within the Meena Bazaar, numerous Delhi Police signs could be found: Sandict Vykation Evam Vaston Se Shavdhan Rehein (Be aware of suspicious people and objects); Bhagdhar naa Machayein (Don't rush/crowd); Bhid-bhad wale ilakon mein Vishish Dhyan Rakhein (Pay special attention to crowded localities). In the Town Hall, a municipal building thronged by citizens completing paperwork, one found this notice: Sediyon ke Kono Mein Na Thu Kein (Please do not spit in the corner of staircases). At the Red Fort, the most prominent heritage building in Old Delhi, a loudspeaker at a police checkpoint played an endlessly looping tape, with exhortations including: Kisi aanjan vyakti se dosti naa karein (Please do not befriend any unknown person). At the Mot Cinema Hall, a popular cinema off Chandni Chowk, which often played Bhojpuri films for labourers, there was a huge placard outside the ticket line, listing the hypothetical possibilities and non-possibilities for cinema-goers. A list of things proscribed, 'Don't', $\mathrm{Na}$ Kare, and a list of things allowed, 'Do', Kare, stood in front of the ticket queue.

In the parks, cinema halls and government offices of the old city, 'spatial etiquette' was demanded (Srivastava 2007: 185). In Delhi's other spaces - the residential colony, the private club - there were 'instructions for use' (Khilnan 1999). In contrast, it was hard to imagine that any rule could be enforced on the street. The impossibility of reform of the street tells us something of its stubborn implacability.

\section{The street: hypertexts and hyperactivity}

In part, it is the street's porosity and stubbornness that has allowed a wider public culture to circulate. I write 'circulate' instead of 'view' or 'see', because writers invariably refer to the optic metaphor when thinking of the street. The citizen's gaze over the street, in this telling, demands 'a particular way of seeing', a requirement of orderly urban space (Chakrabarty 2002: 66).

A good example of the failure of such vision had to do with attempts to standardise storefront fonts. In the Khari Baoli bazaar I learned that municipal officials, as part of their move to beautify the area, demanded that the signs in front of stores be taken down and made uniform. Looking at the bazaar, it was clear that this effort had failed: there were signs in modern, twentieth-century Helvetica; but there were far more that competed frenetically in older, outdated fonts, such as Times and Arial. Indeed, the boards in front of stores were emblems of the individual will of storekeepers rather than impositions of uniformity. Boards overlapped, many tilted precariously and not a few were obscured by handbills or stickers.

Clearly, the planners's desire for soothing uniformity was unfulfilled on the streets of Old Delhi. In other areas, municipal ordinances were pasted over with adverts for aphrodisiacs; modest doorways barely hinted at the frayed courtyards lying beyond them; the jumble of merchants' signboards and plethora of fonts denied easy orientation. Perhaps most importantly, one's vision was constantly overruled by other senses: odorous waves from gutters and railway tracks that make one double over, or inviting scents from kebab sellers; the tinny fragment of film music from a passing bus, or the over-long mobile phone conversation foisted upon you. To reduce the street to a space of middle-class surveillance is an act of impoverishment; there is much happening alongside the citizen's gaze.

The sensory overload of the street is long-standing. In the 1960s, in Agra's old city, the radio was the primary conduit for news, as well as the "nationalized cult of the popular movie song' (Lynch 1969: 168). In the 1980s and 1990s, the television, attached to the tea stall or a shopkeeper's shelf, became the venue around which the masses huddled to compulsively watch television serials. During my time in Old Delhi, the primary medium for communication and entertainment had shifted to the mobile phone. Even men of humble means, such as Rahul, had, or shared, a mobile phone, on which they rang distant relatives, downloaded ringtones and listened to cricket matches. The acoustic cacophony of the old city's street was thus given added dimension by this conduit to elsewhere.

Visually, the old city's street was similarly fecund. Sensational murder stories in Hindi newspapers and gossip magazines could be found in front of sidewalk vendors. They focused on lurid scandals of the present: politicians caught with prostitutes, murders by and of servants, internet videos of teenagers having sex. These topics provided the feedstock for taaza khabar, or salacious news, or chatpati baat, literally spicy talk, the currency of exchange between the city's residents. Advertisements for English classes and sexologists were plastered on urinals and walls, both offering self-improvement of a kind. They reaffirmed, if only in their conjunction, the male and vernacular character of the street (Srivastava 2007).

In these ways, Old Delhi's streets were emphatically physical spaces; their chum left its mark on one's clothes and eardrums. But they were also dream-worlds to elsewhere. Keyboard-clicks allow one entry into parallel experiences. Similarly, 
standing on the city's streets, listening to the conversations and music nearby, looking at the posters and billboards, 'pockets of space are experienced like hypertexts: omnipresent but not always clicked into activation' (Varzi 2006: 128). We could extend this insight further, because the streets of Old Delhi are not just full of hypertexts; the barrage of visual and audio stimuli results in hyperactivity. A good amount of that churn has, of course, to do with film. Even before the urban dweller sees a Bollywood film, or one from smaller film industries in different states, they are floating in its posters and coasting along to its playback music. ${ }^{6}$

Standing in its midst, the street is like facing a desktop with many browser windows open simultaneously, or a TV show overwhelmed by competing adverts and news banners that frame the screen. On those mediated screens, as on the mediated street, there is no main or true or normative street activity. Think of the links you can follow when you surf the internet; do they not make you forget what you were supposed to be doing, constitute a parallel universe, easy to delve into? On the street, one has selective focus, as from a website with too many links, or a TV programme with scrolling news bites. Fragments of information on the street compete for and exhaust one's attention span, deadening as well as enhancing one's senses. This is central to the modern condition of 'anaesthetics', where the shock of work and exhaustion of consumption results in sense-deadening (Buck-Morss 1995).

The workers at Haus Khazi Chowk, dealing with muscle aches, seeking a reprieve from ordinary dullness, imbibed nashas or intoxicants: desi daru or desi sharab (country liquor), as well as tobacco-related products such as beedis, paan, gutka and soorti. The men knew, like most addicts, that these intoxicants accelerated their physical decline. But they felt them necessary, to gain the energy to work, or to receive some peace of mind ( $\mathrm{aram}$ ) and retreat into oneself. The street offered dreamworlds to elsewhere, but its sheer abundance, its endless proliferating desires offered in advertisements and bazaars, deadened one's capacity to domesticate. The mind lit up when men ingested stimulants on the street; the body powered-down through the taking of depressants. The street, as conduit for movement and self-transformation, and site of debasement and anomie, embodied the modern condition. One had to ingest stimulants to work the inhuman hours demanded by the city, building the new emblems of the urban; but they resulted in a subject too wasted to work, staring out, eyes glazed, both distant from, and intertwined with, the street.

\section{Urban beautification and urban ugliness}

I have argued for the street's association with the 'floating population' or popular masses. This relation is pervasive, as the streets of Old Delhi show, but not absolute. A contrast is provided by the middle-class addas of Kolkata, a defining feature of twentieth-century urban modernity in that city. They were, and in a more modest way still are, congregations of friendly gossip between citydwellers, often conducted on the street (Chakrabarty 2000). In a more general way, the iconography of the Indian street - with billboards for the affluent and storefronts for the middle class - presume a stratified population, able to imbibe the deluxe creams and foreign cola advertised (Appadurai 1987: 19). Nevertheless, the altitude of commercial sentiments - always located above the sleeping homeless or hunched-over day labourers - tells us something about the street's symbolic gradient. Moreover, in recent years, as the underclass ethos of the black town has seeped into other parts of the Indian city - through slums on public land, for example - elites have become more wary of the street, retreating intỏ their drawing rooms (Mazumdar 2008).

In colonial and post-independence India, the street - a space of bazaar rumours, delinquent youth and subversive nationalists - was an official obsession. The history of Indian cities is often written as a fall from grace, such that the 'plebianisation of public space appears irreversible' (Kaviraj 1997: 108). But looked at over the long term, the Indian street has always been for the plebes; their appearance is not novel, but long-standing.

Nineteenth-century regulations against gambling, for example, targeted the street and other popular gathering spots, but left such practices alone when they were carried out in the private homes of the gentry (Birla 2009: 154). In colonial and postcolonial Calcutta, halla, 'sudden, violent police action aimed at clearing streets of hawkers and vendors' was widespread (Chakrabarty 2002: 77). In the early twentieth century, state planners, elite reformers in Uttar Pradesh's large cities, targeted 'the immorality and vulgarity of plebeian and street culture' (Gooptu 2001: 240). This anxiety about the street's underclass ethos emerged during the Emergency of 1975-77. At that time, Prime Minister Indira Gandhi suspended democracy, and bureaucrats effected the 'beautification' of Delhi's streets, through the removal of slums and pavement dwellers (Tarlo 2003).

To retum to Delhi's old city, municipal authorities, when performing their role as the guardians of law and order, often turned to its street to demonstrate their vigilance. Very Important Persons, or VIPs, constitute an important political caste in India's capital. Still, they are not so valued as to deserve one further adverb; that is the preserve of the handful within the category Very, Very Important Persons - VVIPs. When members of either exalted category toured the old city, to announce their interest in the nation's heritage, for example, Rahul and his ilk were cleared beforehand by the police. Such performances were mutually deceptive. Politicians and elite VIPs and VVIPs pretended that their presence was not the cause of the street's strange emptiness. Subsidiary officials and police pretended that they did not aid and abet the kinds of street hawking and encroachment that lined their pockets. The street was here a particularly self-conscious theatre. As soon as the VIPs and VVIPs left the streets of the old city, their official ambassadors snaking away in a coordinated series of blinking rooftop lights, the street returned to its occupied, unkempt frenzy.

For the men of the street, for workers such as those at Haus Khazi Chowk, urban cleansing of this type was a familiar pattern. It was like a rhythmic flooding of the plains that could, as with seasonal cycles, be plotted temporally. Other causus belli were possible, beyond the presence of the very important. Prior to national holidays and election polls, for example, the workers of Haus Qazi Chowk 
284 A. Gandhi

were shunted into spartan concrete shells, charitably termed rehan basaras, or night shelters. Another category of urban beautification reached Rahul and his fellow workers more prosaically. After shopkeepers complained to the police about pavement encroachment the labourers grudgingly retreated to nearby parks.

\section{Conclusion}

This chapter has sought to identify some features that define the street in Old Delhi, and, by extension, other postcolonial streets. It has emphasised how plebeian and performative streets are, and how, for the proletarian masses, the street is both a window of opportunity and sinkhole of failure. It has put forward an analytical vocabulary for revising how the postcolonial street is conceived; abundance and plasticity, osmosis and porosity, and altitude and adjustment allow us to apprehend the street's circulatory and shape-shifting nature. In this process, this chapter has highlighted a central tension exemplified by the streets of Old Delhi. On the one hand, they are, as in many modern cities, a source of enormous anxiety: governments, in 1857, 1947, 1976 and 2010, made serious attempts to reform the streets of the old city. Yet, on the other, the street is a terminally unkempt but vital entity. The Indian street has repeatedly been a target of official rationalisation, yet it has retained its own durable character.

Like an ingeniously moulded toy, which can weather numerous blows only to return to its original shape, the street, having endured thousands of police and municipal raids, invariably returns to an enduring, autonomous shape. The plasticity of the street, its ability to persist while facing enormous, countervailing pressures, is a metaphor for the Indian old city. It lingers not out of subaltern resistance, or indigenous continuity: none of the workers at Haus Khazi Chowk, in Delhi's old city, celebrate the fact that they eat, defecate, shower and entertain each other on the street. In all of its unruliness, lacking the prescriptions undergirding other urban spaces, the street remains the defining haunt of the male, popular masses.

\section{Notes}

1 Oldenburg (1976: 63) discusses how the chowk, broader and busier than the lane, produces a distinct urban public. Chowks are where politicians become visible by strolling; passers-by converge there at tea and tobacco stands; and newspapers are placed on street platforms and read communally.

2 Indeed, the Indian street is far from neutral, public territory; the long history of religious processions, rampaging mobs and jeering crowds on the street show it can be potentially malevolent: 'during periods of riot in Hyderabad's walled city, an innocuous strip of road often becomes enemy territory. A person may well find crossing that strip of road to get to the safety of his home a terrifying experience' (Naidu 1990: 44).

3 Clearly, many postcolonial streets outside of India exhibit such features. For an analogous example from Africa, one could look to Lagos. There, on a map, expressways still looked like channels. Actually,

Lagos has no streets; instead it has curbs and gates, barriers and hustlers that control separate landscapes. Some areas might look like streets; they might even
The postcolonial street 285

look like superhighways. But even the Lagos superhighway has bus stops on it mosques under it, markets in it and buildingless factories throughout it. Lagos is as much a system of circulation as it is any particular place ... Its roads are not plan lines between points, but perhaps its most elastic and variable scapes, made more enabling by local modifications which deny the road's insistent linearity guardrails are removed, jersey barriers put aside. At all bottlenecks, the road is gurdrails are

(Koolhas et al. 2000: 686)

4 See Coelho (2006) for an analogous study of urban infrastructure in Chennai. Underground water distribution is theoretically channelled through a formal grid and preordained supply levels. Actually it is subject to innumerable compromises. These provisional but actually widespread and therefore constitutive forms include bypass connections, illegal siphoning and temporary compromises.

5 In a city with nearly 3,200 public urinals in 2007 , only 132 were for women. These public toilets are widely considered unsanitary, and surrounded by fears of sexual assault, resulting in recalcitrance in using them. Therefore, it is not surprising that health problems such as constipation, piles and urinary tract infection are more prevalent amongst urban women than men. See Aastha Atray Banan's 'Why Women Should Not Hold On', Tehelka, 24 July 2010: 56-57.

6 An observer of Tamil cinema in the south Indian city of Madurai notes:

In the city of Madurai, cinema is everywhere. Glittering billboards advertise the latest films, and smaller posters are slapped on to spare inches of wall space. Movie songs blare from hom speakers and cassette players at weddings, puberty rites, and temple and shrine festivals. Tapes of movie dialogues play at coffee rites, and temple and shrine festivals. Tapes of movie dialogues play at coffee
stalls, while patrons join in reciting them. Rickshaws and shop boards are painted with movie stars' pictures.... Fan-club members meet in the streets to boast about their star and make fun of his rivals.

(Dickey 1993: 3)

\section{References}

Appadurai, A. (1987) 'Street Culture'. The India Magazine 8 (1): 2-23.

Baudelaire, C. (1997) The Parisian Prowler: Le Spleen De Paris, Petits Poemes En Prose [trans. E. Kaplan]. Athens: University of Georgia Press.

Benjamin, W. (1983 [1973]) Charles Baudelaire: A Lyric Poet in the Era of High Capitalism [trans. H. Zohn]. London: Verso.

Berman, M. (1982) All That Is Solid Melts into Air: The Experience of Modernity. New York: Simon and Schuster.

Birla, R. (2009) Stages of Capital: Law, Culture, and Market Governance in Late Colonial India. Durham, NC: Duke University Press.

Buck-Morss, S. (1995) 'The City as Dreamworld and Catastrophe'. October (Summer): 3-26. Chakrabarty, D. (2000) Provincializing Europe: Postcolonial Thought and Historical Difference. Princeton, NJ: Princeton University Press.

Chakrabarty, D. (2002) Habitations of Modernity: Essays in the Wake of Subaltern Studies. New Delhi: Permanent Black.

Chandavarkar, R. (1998) Imperial Power and Popular Politics: Class Resistance and the State in India c. 1850-1950. Cambridge: Cambridge University Press.

Coelho, K. (2006) 'Tapping In: Leaky Sovereignties and Engineered (Dis)Order in an Urban Water System', in M. Narula, S. Sengupta, R. Sundaram, J. Bagchi, A. Sharan and G. Lovink (eds), Sarai Reader 2006: Turbulence. Delhi: CSDS. 
de Certeau, M. (1988 [1984]). The Practice of Everyday Life. Berkeley, CA: University of California Press.

Dhand, A. (2006). 'The Practice of Poetry Among a Group of Heroin Addicts in India: Naturalistic Peer Learning'. Ethnography and Education 1 (1): 125-141.

Dickey, S. (1993) Cinema and the Urban Poor in Urban India. Cambridge: Cambridge University Press.

Freitag, S. (ed.) (1989) Culture and Power in Banaras: Community, Performance, and Environment, 1800-1980. Berkeley, CA: University of California Press.

Gooptu, N. (2001) The Politics of the Urban Poor in Early Twentieth-Century India Cambridge: Cambridge University Press.

Hansen, T.B. \& O. Verkaaik (2009) 'Introduction: Urban Charisma - On Everyday Mythologies of the City'. Critique of Anthropology 29 (5): 5-26.

Hjortshoj, K. (1979) Urban Structures and Transformations in Lucknow, India. Cornell, NY: Cornell Program on International Studies in Planning.

Jeffrey, C., P. Jeffery \& R. Jeffery (2008) Degrees without Freedom? Education, Masculinities and Unemployment in North India. Stanford, CA: Stanford University Press.

Kaviraj, S. (1997) 'Filth and the Public Sphere: Concepts and Practices About Space in Calcutta'. Public Culture 10 (1): 83-113.

Khilnani, S. (1999) The Idea of India. New Delhi: Penguin.

Koolhaas, R. (2000) 'Lagos', in R. Koolhaas, S. Boeri, S. Kwinter, N. Tazi \& H. Ulbrich Obrist (eds), Mutations. Barcelona: ACTAR.

Kumar, N. (1988) The Artisans of Banaras: Popular Culture and Identity, 1880-1986. Princeton, NJ: Princeton University Press.

Lynch, O. (1969) The Politics of Untouchability: Social Mobility and Social Change in a City of India. Delhi: National Publishing House.

McDonough, T. (ed.) (2009) The Situationists and the City. London: Verso.

Mazumdar, R. (2008) 'Spectacle and Death in the City of Bombay Cinema', in G. Prakash \& K. Kruse (eds), The Spaces of the Modern City: Imaginaries, Politics, and Everyday Life. Princeton, NJ: Princeton University Press.

Mehta, D. (1997) Work, Ritual, Biography: A Muslim Community in North India. Delhi: Oxford University Press.

Naidu, R. (1990) Old Cities, New Predicaments: A Study of Hyderabad. Delhi: Sage.

Nair, J. (2005) The Promise of the Metropolis: Bangalore's Twentieth Century. Delhi: Oxford University Press.

Oldenburg, P. (1976) Big City Government in India: Councilor, Administrator, and Citizen in Delhi. Delhi: Manohar.

Oldenburg, V.T. (2001 [1984]) The Making of Colonial Lucknow 1856-1877. Delhi Oxford University Press.

Ramaswami, S. (2007) 'Masculinity, Respect, and the Tragic: Themes of Proletarian Humor in Contemporary Industrial Delhi', in R. Behal \& M. van der Linden (eds), India's Labouring Poor: Historical Studies, c. 1600-C.2000. Delhi: Foundation Books.

Srivastava, S. (2007) Passionate Modernity: Sexuality, Class, and Consumption in India. Delhi: Routledge.

Tarlo, E. (2003) Unsettling Memories: Narratives of the Emergency in Delhi. London: Hurst \& Company.

Varzi, R. (2006) Warring Souls: Youth, Media and Martyrdom in Post-Revolution Iran. Durham, NC: Duke University Press.

Vidal, D. \& N. Gupta (1999) 'Urban Vocabulary in Northern India'. UNESCO working paper.

\section{Life stories of the urban poor in Chittagong, Bangladesh}

Mineo Takada

Chittagong is the second largest city in Bangladesh, after the capital, Dhaka, and has a population of several million. As a port city, Chittagong has vast numbers of lower-strata labourers. They and their families support the city from below, and in this sense they are among the most typical city dwellers. ${ }^{1}$ This chapter deals with cases of people who live and work in this city. All the interviewees are migrants from rural villages, and have thus experienced both rural and urban life. Therefore, images of the city and urban life can be expected to emerge from such narratives, particularly from those who have experienced life in the city. Further, their views reflect the comparative perspective that contrasts the urban (life) against the rural (life). The urban 'lower strata' in this chapter is generally composed of people living in a Bangladeshi city - in this case Chittagong - and working in jobs typically belonging to the informal sector.

The author conducted interviews with many people, but this chapter presents mainly excerpts from the narratives of three individuals. They are Haydar, Hakim and Khokon, all of whom are Muslim men. Haydar (aged about 50) is a riksa (rickshaw) painter, and Hakim (aged about 60) is the owner of a riksa garage - he owns many riksas and a private riksa company. Hakim was originally a riksa painter, and Haydar was his apprentice. By contrast, Khokon (in his mid-forties) is a cook who prepares dishes ordered by his clients for parties. He has no relationship to the other two men. ${ }^{3}$ Complimenting these accounts, some narratives from other interviewees will also be presented. The 'oral history' method is employed in this chapter in order to allow the voice of the person concerned to be heard. ${ }^{4}$ Broadly speaking, many urban studies tend to pay attention to those people whose voices are loudest, and to ignore or under-estimate the voices, feelings or thoughts of the people who belong to what might be called the lower strata of society, or to the silent majority. For various reasons, their voices struggle to reach the ear of the hearer. By contrast, those studies that use the oral history method are exemplary in setting out to hear the voices of the people and to correct the bias of previous studies. 